\title{
KONSEP PENDIDIKAN PEMBEBASAN MANSOUR FAKIH
}

\author{
Amir Rifa'i \\ Universitas Muhammadiyah Malang \\ E-mail: amirrifaisma@gmail.com
}

\begin{abstract}
Abstrak
Penelitian ini bertujuan untuk mengkaji konsep pendidikan pembebasan Mansour Fakih dan relevansinya dengan pendidikan Islam. Hasil penelitian ini diharapkan dapat memberikan solusi atau sumbangan pemikiran bagi tujuan pendidikan islam. Penelitian ini merupakan jawaban dari pertanyaan tentang pendidikan pembebasan Mansour Fakih dan penelitian ini menggunakan kualitatif, sedangkan metode yang digunakan dalam penelitian ini adalah studi pustaka (Library Research), pengumpulan data dilakukan dengan cara penelusuran terhadap karya-karya Mansour Fakih terutama tentang pendidikan. Sedangkan analisis data yang digunakan dalam penelitian ini adalah analisis wacana yang akan mengungkap berbagai literature dari objek penelitian. Hasil dari penelitian ini menunjukkan bahwa 1). Konsep pendidikan pembebasan Mansour Fakih adalah tentang pendidikan pembebasan secara kritis, yang bila diambil benang merahnya adalah pendidikan tidak memebelenggu peserta didik untuk mengembangkan kreatifitasnya. Dengan bercirikan pertama, belajar dari pengalaman, kedua, tidak menggurui, ketiga, dialogis. 2). Relevansi pendidikan Mansour fakih dengan pendidikan Islam. Dari konsep pendidikan pembebasan Mansour Fakih dengan pendidikan Islam adalah bahwa keduanya sama-sama tidak menginginkan pendidikan yang membelenggu karena hakekat manusia adalah bebas.
\end{abstract}

Kata Kunci: Mansour Fakih, Pendidikan Pembebasan.

\begin{abstract}
This research has purpose to discuss about the educational concept of Mansour Fakih's liberation and the relevance with Islamic education. The expectation of this research's result is to give a solution or an idea for the purpose of Islamic education. This research is an answer from the Mansour Fakih educational liberation's question, and it uses qualitative research whereas the method is library research. The collecting data have been done by investigating Mansour Fakih's work especially about education while the data analysis that is used is word analysis which will express some literature from the research's object. The research's result shows that: 1. The educational concept of Mansour Fakih's liberation is about critical liberation education that can be concluded as the education that doesn't restrict the pupils to develop their creativities with some characteristics that are learning from experiences, not teaching, and dialogis 2. The relevance of Mansour Fakih education with Islamic education. From the educational concept of Mansour Fakih's liberation with Islamic education is that both of them do not wish for the education that restrict because human's essence is free.
\end{abstract}

Keyword: Mansour Fakih,Liberation Education.

\section{Pendahuluan}

Pendidikan adalah sarana untuk mencerdaskan anak bangsa yang bisa membawa kepada pencerahan secara keseluruhan, pendidikan juga bertujuan untuk membangun sebuah bangunan bangsa yang melekat dengan nilai-nilai kecerdasan, kepekaan dan kepedulian terhadap bangsa dan negara. 


\section{8 | Konsep Pendidikan Pembebasan Mansour Fakih}

Semakin berkembang dunia ini, semakin berkembang pula pendidikan dan dalam perkembanganya tersebut, dituntut untuk mendeklarasikan sebuah gaya yang "berbeda", supaya bisa menjadi lebih baik dari masa ke masa (progressive).

Pendidikan harus mampu mewujudkan manusia yang seutuhnya, karena berfungsi sebagai proses penyadaran terhadap manusia untuk mampu mengenal, mengerti dan memahami relitas kehidupan sehari-hari. Kunci pendidikan, adalah kemanusiaan. Bahkan kurang lebih 600 tahun SM di Yunani, telah dideklarasikan bahwa "Pendidikan adalah usaha membantu manusia menjadi manusia."1 Dengan demikian, relasi antara perkembangan zaman dengan kesadaran pendidikan adalah harus secara progresif bersesuaian dengan perkembangan zaman, kebudayaan, pemikiran, sains dan teknologi yang berlandaskan kemanusiaan sejati.

Pendidikan sangat penting di seluruh aspek kehidupan. Akan tetapi selama ini banyak orang yang mengartikan bahwa pendidikan adalah sebuah proses belajar mengajar secara formal saja. Padahal pendidikan sebagai aktivitas penyadaran kemanusiaan, bisa dilakukan oleh siapa-pun dan di mana-pun, termasuk di rumah. Jelas sekali bahwa pandangan ini merupakan sebuah kekurangan bila dibandingkan dengan tujuan luhur pendidikan.

Pendidikan formal maupun non formal adalah satu kesatuan. Satu tujuan integratif menyangkut pendidikan adalah untuk memanusiakan manusia. Cita-cita humanisme pendidikan yang utama adalah membuka ruang dialog untuk keadilan kemanusiaan. Tidak ada sekat sama sekali yang meminggirkan hak kemanusiaan.

Bila dalam dunia pendidikan masih terbatasi oleh sekat sosial tertentu, belumlah dikatakan bahwa pendidikan itu sudah manusiawi. Karena itu dalam agenda humanisasi pendidikan, keadilan sosial adalah prinsip yang utama. Pendidikan yang masih menaruh perhatian dan melayani hanya satu golongan tertentu serta mengikuti trend dan kepentingan akumulasi profit para pemilik kapital bahkan cenderung menginjak martabat kemanusiaan, maka itu bukanlah filsafat pendidikan yang sesungguhnya. Dengan kata lain, pemahaman atas filsafat pendidikan yang dimengerti saat ini, masih melayani kehendak kepentingan pribadi tertentu, atau kehendak politik yang dehumanistik dan imoral.

Sebenarnya filsafat pendidikan adalah sebuah penghormatan terhadap pengetahuan yang luhur dalam proses dialogis. Guru dan murid saling memberi dan mengapresiasi pengetahuan. Tidak ada manusia yang bodoh dan tidak ada pula siapa pun yang paling pintar di antara manusia lainnya. Murid adalah guru bagi gurunya, dan guru adalah fasilitator yang memacu dan memicu percepatan meraup limpahan pengetahuan. Karena itu, setiap pendidikan harus memiliki garis-garis halauan sebagai petunjuk praksis pendidikan yang jelas dan menjunjung humanisme. Tidak terkecuali juga di Indonesia. Dengan pelbagai masalah yang dialami bangsa ini, maka pendidikan harus tetap teguh untuk berpegang terhadap kredo utamanya, humanisme.

1 Ahmad Tafsir, Filsafat Pendidikan Islami: "Integrasi Jasmani, Rohani dan Kalbu Memanusiakan Manusia” (Bandung: Bumi Aksara, 2006), hal. 33. 
Berbicara tentang pendidikan yang humanis, berarti sama halnya membicarakan pendidikan sebaliknya. Karena humanisme akan menjadi berarti ketika ada upaya pembebasan terhadap segala tindak laku yang anti kemanusiaan. Dalam dunia pendidikan, secara sadar maupun tidak kita seringkali dibodohi dengan praktik pendidikan yang sangat kurang bermutu. Terlebih bahwa pendidikan saat ini memiliki trend "mutu" yang lebih mementingkan taraf internasional. Dengan kata lain, kualitas yang baik, sebenarnya ditentukan oleh internasionalisasi lembaga formil pendidikan.

Suatu hal yang memprihatinkan ketika melihat bahwa internasionalisasi sebenarnya hanyalah klasifikasi sosial pendidikan yang melayani kehendak pasar bebas dan kapitalisme. Pendidikan akan dianggap lebih terhormat dibanding yang lain, bila memiliki kapital yang kuat. Kekuatan kapital inilah yang selalu menjadi dasar pendidikan dan kependidikan, dari pada pembebasan kemanusiaan.

Fakta dewasa ini, mencatat bahwa praktik pendidikan masih tergolong "tebang pilih".2 Siapa yang memiliki kualitas finansial yang baik, maka dia bisa mendapatkan pendidikan yang terbaik. Uang yang selalu berjalan seperti di pasaran dan hasilnya siswa menjadi pembeli sedangkan sang guru menjadi penjual. ${ }^{3}$ Pendidikan semacam ini akan menjadikan sekolah sebagai penentu akumulasi profit kapitalis, bukan kecerdasan dan kreatifitas. Dengan demikian, pendidikan adalah komoditas.

Pasar, dalam wacana ini telah menjadi penjajah kesadaran kritis. Tidak hanya itu, yang lebih parah lagi telah menjadi pemutus harapan bagi kelas termarginalkan. ${ }^{4}$ Praktik pendidikan pasar juga dilakukan dengan cara menggratiskan biaya sekolah, namun tetap saja mengambil pungutan dan menambah tarif biaya buku atau Lembar Kerja Siswa (LKS). Atas dasar fenomena tersebut, malah pemerintah melakukan pembiaran atas segala praktik pendidikan yang berorientasi pasar. ${ }^{5}$

Selain praktek pendidikan mahal, kasus pembodohan juga kerap sekali terjadi di dunia pendidikan saat ini. Anak-anak yang dibiarkan di dalam lingkungan yang sangat memprihatinkan ini, tentu memerlukan pendidikan yang penuh dengan harapan. Bukan hanya pendidikan yang memposisikan peserta didik sebagai objek dari perubahan, melainkan pendidikan yang memerankan mereka sebagi manusia yang memiliki hak (the pedagogy of hope). Sayangnya, di sekolah, murid diibaratkan hanya sebagai sebuah wadah, dan guru atau pendidik berperan untuk mengisi wadah itu dengan pengetahuan. Murid hanya menerima, tanpa diajak untuk berpikir kritis, bagaimana memahami kondisi sosialnya dan memiliki kesadaran untuk merubah kondisi tersebut dari segala keterbatasan, menuju situasi yang lebih membebaskan.

Siswa dalam proses pembelajarannya, mempunyai hak untuk mendapatkan pelajaran yang lebih manusiawi. Setiap anak didik memiliki hak untuk memilih peran mereka sendiri. Seorang pendidik tentunya harus

\footnotetext{
2 Eko Prasetyo, Guru: Mendidik itu Melawan (Yogyakarta: Resist Book, 2006), hal. 96.

${ }^{3}$ Ibid.,

${ }^{4}$ Ibid., hal. 98.

5 Ibid., hal. 31.
} 


\section{0 | Konsep Pendidikan Pembebasan Mansour Fakih}

mempunyai ide yang layak bagi seorang anak, yang semata-mata bukan hanya kumpulan siswa, tetapi seseorang yang punya kaitan dengan lingkungan sosialnya. ${ }^{6}$ Sudah sepatutnya, guru adalah fasilitator untuk meraup segala jenis kesadaran kritis. Bila guru merasa dirinya serba tahu seperti Tuhan, maka murid tidak pernah berdaya, terlebih bahwa murid tidak memiliki kesempatan untuk agenda transformasi sosial sesuai dengan situasi dan kondisi yang dialaminya.

Senada dengan hal ini, Paulo Freire secara sederhana menyusun daftar antagonisme pendidikan "gaya bank" untuk menyebut segala praktik penindasan di dunia pendidikan. Menurutnya, pendidikan yang menindas tersebut adalah

1. Guru mengajar, murid belajar,

2. guru tahu segalanya, murid tidak tahu apa-apa,

3. guru berpikir, murid dipikirkan,

4. guru bicara, murid mendengarkan,

5. guru mengatur, murid diatur

6. Guru memilih dan memaksakan pilihanya, mmurid menuruti

7. Guru bertindak, murid membayangkan bagaimana bertindak sebagaimana bertindak seperti gurunya.

8. Guru memilih apa yang akan diajarkan, murid menyesuaikan diri

9. Guru mengacaukan wewenang ilmu pengetahuan dengan wewenang profesionalismenya, dan mempertentangkanya dengan murid-murid

10. Guru adalah suibjek proses belajar, murid objeknya." 7

Jelas hal ini sangat berlawanan dengan hakikat pendidikan sebagai proses memanusiakan manusia kembali. ${ }^{8}$ Dari sini, muncullah gagasan pendidikan yang diharapkan mampu memberi jawaban yang selama ini cukup meresahkan martabat kemanusiaan. Pelbagai problem di atas adalah kegagalan pemerintah dalam menyelenggarakan pendidikan yang berkualitas. Karena itu, gagasan pendidikan kritis yang membebaskan adalah solusi yang ditawarkan dalam menjawab tantangan zaman kini.

Pendidikan kritis bukan wacana baru, namun sudah lama berkembang. Kendati demikian, pendidikan kritis harus selalu disuarakan karena menjadi kelanjutan dari agenda gerakan pembebasan. ${ }^{9}$ Secara filosofis, pendidikan kritis dan pembebasan pada dasarnya merupakan dua hal yang tidak bisa dipisahkan. ${ }^{10}$

Istilah pembebasan muncul sebagai gugatan karena ketergantungan terhadap sistem kapitalisme, pengekangan guru dan kurang menghargai kreatifitas siswa sebagai peserta didik. Hal ini sungguh akan merugikan generasi muda di masa mendatang. Di sinilah pentingnya setiap individu

${ }^{6}$ Ibid., hal. 99.

"Paulo Freire, Politik Pendidikan: "Kebudayaan, Kekuasaan dan Pembebasan" (Yogyakarta: Pustaka Pelajar, 2007), hal. Xi.

8Mansour Fakih et.al., Pendidikan Populer, Membangun Kesadaran Kritis

(Yogyakarta: INSIST Press, 2005), hal. Xvi.

${ }^{9}$ Ibid., hal. 42.

10 Ibid., 
terlibat dalam proses pendidikan, untuk menyadarkan semua kalangan masyarakat. ${ }^{11}$ Pembacaan baru tentang konsep pembebasan ini, sangat menarik untuk dikaji secara serius.

Salah satu pemikir dan juga praktisi pendidikan yang sangat selalu menyuarakan konsep pembebasan terhadap pendidikan adalah Mansour Fakih. Ia adalah salah satu aktivis organisasi non pemerintah (Non Government Organisation) dan juga tokoh pendidikan, yang secara intens mengkritik praktik pendidikan yang selama ini ada di Indonesia. Fakih, selalu mencoba menawarkan solusi ilmiah dan rasional guna perbaikan pendidikan dewasa ini.

\section{Metode}

Penelitian ini merupakan penelitian kualitatif, di mana data yang hendak diteliti, adalah data-data yang memiliki kualitas makna-makna tertentu. Metode penelitian ini adalah library research atau kajian pustaka. Kajian pustaka yang mengungkapkan konsep-konsep baru dengan cara membaca dan menganalisis segala tulisan Mansour Fakih yang ada tentang pendidikan, politik, maupun kebudayaan. Penelitian ini dikhususkan pada pemikiran pendidikan DR. Mansour Fakih seputar konsep pendidikan pembebasan. Adapun yang menjadi objek studi dari judul yang diambil adalah beberapa buku karya DR. Mansour Fakih. Analisis yang dipakai dalam penelitian ini adalah analisis wacana dengan memperhatikan tindakan, konteks, historis dan kekuasan. Selain itu, alasan peneliti menggunakan analisis wacana ini dan tidak menggunakan analisis isi adalah karena analisis isi tidak mampu untuk menentukan contoh yang sangat relevan sesuai dengan yang di inginkan peneliti dan juga tidak mampu memberikan definisi oprasional dari topik yang diteliti. ${ }^{12}$

\section{Pemikiran Pendidikan Pembebasan Mansour Fakih}

Pendidikan pemebebasan yang digagas oleh Mansour Fakih bukan konsep pendidikan yang baru akan tetapi sudah pernah digagas oleh Paulo Freire yang juga tokoh pembebasan dari Barsil. Sementara itu, Mansour Fakih lebih dikenal sebagai orang yang paling giat dalam mengembangkan model pendidikan pembebasan di Indonesia ini. Menurut Mansour Fakih ada dua teori pendidikan secara umum yaitu teori reproduksi dan teori produksi. Dalam teori reproduksi, pendidikan merupakan alat dominasi yang selalu digunakan demi melenggangkan atau melegitimasi dominasi tersebut. Sementara teori produksi dalam pendidikan merupakan model pendidikan yang bertujuan untuk membangun kesadaran kritis, kesadaran pekerja yang ditindas oleh pimpinan, orang kaya yang diperbudak oleh harta, orang miskin yang dieksploitasi oleh konglomerat bahkan untuk anak didik yang ditindas

11 Azzet Muhaimin, Pendidikan yang Membebaskan (Yogyakarta: Ar-Ruz Media, 2011), hal. 9.

12 Burhan Bungin, Penelitian Kualitatif (Jakarta: 2010), hal. 118. 


\section{2 | Konsep Pendidikan Pembebasan Mansour Fakih}

oleh Negara, model pendidikan yang kedua inilah yang menjadi akar dari pendidikan kritis.

Model pendidikan yang kedua ini lebih merupakan proses pembebasan manusia, yang mengasumsikan bahwa manusia dalam sistem dan struktur sosial yang ada pada dasarnya mengalami proses dehumanisasi karena eksploitasi kelas, dominasi gender maupun karena hegemoni dan dominasi budaya lainya. ${ }^{13}$

Oleh karena itu pendidikan merupakan suatu sarana untuk "memproduksi" kesadaran untuk mengembalikan kemanusiaan manusia, dan dalam kaitan ini, pendidikan berperan untuk membangkitkan kesadaran kritis sebagai prasarat upaya untuk pembebasan. ${ }^{14}$ Hal ini berarti pendidikan harus memberi ruang untuk menyingkirkan segenap hal tabu dan menentang secara kritis hegemoni dominan dalam bentuk sistem dan struktur yang tidak adil yang tengah berlaku. ${ }^{15}$

Selanjutnya bagaimanakah proses pembebasan dan proses belajar untuk membangkitkan kesadaran kritis dan pembebasan dilakukan? Banyak pendidik dalam menjawab pertanyaan ini umumnya lebih konsentrasi pada metode ketika proses belajar diselenggarakan. ${ }^{16}$ Namun sesungguhnya, pendidikan tidak pernah berdiri bebas tanpa berkaitan secara dialektis dengan lingkungan dan sistem sosial di mana pendidikan diselenggarakan. Proses pendidikan sebagai proses pembebasan tidak pernah terlepas dari sistem dan struktur sosial, yakni konteks sosial yang menjadi penyebab atau yang menyumbangkan proses dehumanisasi dan keterasingan pada waktu pendidikan itu diselenggarakan.

Apalagi dalam era Globalisasi Kapitalisme seperti saat ini, pendidikan dihadapkan pada tantangan bagaimana mengkaitkan konteks dan analisis isinya untuk memahami globalisasi secara kritis. Strategi pada umumnya para pendidik lebih tertuju untuk bagaimana membuat proses belajar mereka relevan terhadap formasi sosial yang dominan saat ini, yakni globalisasi kapitalisme dan menguatnya Neoliberalisme. ${ }^{17}$ Strategi seperti ini lebih berkesan menerima dan mensiasati dan justru sering menjebak untuk penyesuaian terhadap globalisasi. Sementara itu jarang proses belajar yang mengintegrasikan analisis globalisasi dan bagaimana mereka berperan dengan proses kritik dan melakukan dekonstruksi, untuk menemukan solusi alternatif terhadap globalisasi, misalnya menciptakan diskursus tandingan terhadap diskursus globalisasi yang dominan dengan perspektif alternative dan juga membuat pendidikan kritis.

Dalam pendidikan kritis, tugas yang dibawa oleh pendidikan adalah melakukan refleksi kritis terhadap sistem dan ideologi dominan yang tengah

13 Ibid., hal. xi

14 Mansour Fakih, Masyarakat Sipil dan Transformasi Sosial, (Yogyakarta: Pustaka Pelajar, 1996), hal.63

15 Mansour Fakih, Jalan Lain Manifesto Intelektual Organik, ( Yogyakarta: Pustaka Pelajar, 2011), hal. 144

16 Mansour Fakih, Runtuhnya Teori Pembangunan dan Globalisasi, (Yogyakarta: INSIST Ppess, 2009), hal. 158

17Mansour Fakih, Sebuah Pengantar dalam buku Francis Wahono, Kapitalisme penddikan Antara Kompetisi dan Keadilan, (Yogyakarta: Pustaka Pelajar, 2001), hal. xi 
berlaku dimasyarakat, serta menentang system tersebut untuk memikirkan sistem alternative ke arah transformasi sosial menuju suatu masyarakat yang adil.

Pendidikan kritis adalah pendidikan yang digagas oleh Mansour Fakih dalam melenggangkan pendidikan pembebasan di Indonesia. Dan dalam pendidikan kritis mempunyai asumsi bahwa ada beberapa komponen yang terkandung dalam pendidikan kritis.

\section{Komponen Pendidikan Pembebasan Kritis a. Asumsi-asumsi dasar Pendidikan Kritis}

Asumsi adalah sebuah anggapan yang dianggap benar, sedangkan yang dimaksud dalam wacana ini merupakan hal yang mendasar dalam memaknai pendidikan, demikian pula pendidikan kritis yang tidak bisa lepas dari asumsi bahwa pendidikan hendaklah bersikap kritis. Artinya adalah dengan memahami asumsi dasar pendidikan kritis maka siapapun berhak mengatakan bahwa sebuah proses pendidikan disebut sebagai pendidikan kritis.

\section{b. Fasilitator}

Fasilitator bisa diartikan dengan orang yang bertugas untuk memperlancar sebuah proses supaya bisa memperlancar tujuan yang diinginkan. Sedangkan fasilitator yang dimaksud dalam pendidikan kritis ini adalah seseorang yang memfasilitasi peserta didik untuk mengadakan transformasi di dalam masyarakatnya, dari kondisi yang tidak adil menuju kondisi yang lebih adil. Usaha mentransformasi mengindikasikan bahwa fasilitator faham akan struktur yang menindas dalam masyarakat tersebut dan juga tahu apa yag seharusnya dilakukan untuk menuju kepada kondisi yang lebih baik. Walaupun dalam kenyataanya kadang dan sering peserta didik mempunyai strategi yang lebih aplikatif daripada fasilitator. ${ }^{18}$

Dengan demikian fasilitator yang memang beraksi lokal tapi harus memiliki wawasan yang global akan perkembangan masyarakat khususnya yang berhubungan dengan paradigma-paradigma sosial.

\section{c. Metode Pendidikan Kritis}

Pendidikan kritis mengharuskan metode pembelajaran yang membebaskan yaitu, dari, oleh dan untuk peserta didik. "Dari" yaitu karena peserta didik mengalami proses penindasan baik disadari atau tidak. "Oleh" artinya peserta tidak menganalisa masalah yang mereka hadapi kemudian menyimpulkan dan melakukan aksi untuk merubah dirinya yang tentunyya difasilitasi oleh fasilitator. Dan "untuk" artinya proses pembelajaran hanyalah untuk menyelsaikan maslah yang mereka hadapi. ${ }^{19}$ Dengan demikian pendidikan kritis sebenarnya lebih condong menanggapi pertanyaan dan menyelesaikan masalah peserta didik disbanding mencari kebenaran obyektif yang ilmiah tapi malah tidak dapat menyelesaikan system pendidika

18 Ibid., hal. xix

19 Ibid., hal. 75 


\section{4 | Konsep Pendidikan Pembebasan Mansour Fakih}

tersebut. Sedangkan hal lain yang perlu diperhatikan dalam metode pendidikan kritis adalah diantaranya ada hubungan yang horizontal antara peserta didik dengan fasilitator.

\section{Proses Pendidikan Kritis}

Mansour Fakih mengatakan bahwa pendidikan kritis adalah pendidikan yang mengarahkan pendidikan untuk merefleksikan kritis terhadap idiologi dominan kearah transformasi sosial. Pendidikan kritis adalah pendidikan yang berusaha menciptakan ruang untuk mengidentifikasi dan menganalisis segenap potensi yang dimiliki oleh peserta didik secara bebas dan kritis untuk mewujudkan transformasi sosial. ${ }^{20}$ Melihat dasar filosofis dari pendidikan kritis di atas, maka selanjutnya ada 3 (tiga) ciri pokok pendidikan kritis.

\section{a. Belajar dari Realitas atau Pengalaman}

Apa yang dipelajari bukan ajaran (teori, pendapat, kesimpulan, wejangan, nasihat, dan seterusnya) dari seseorang, tetapi keadaan nyata masyarakat atau pengalaman seseorang atau sekelompok orang yang terlibat di atas keadaan nyata tersebut. Akibatnya, tidak ada otoritas pengetahuan seorang yang lebih tinggi dari lainnya. Keabsahan pengetahuan seorang ditentukan oleh pembuktiannya dalam realitas tindakan/pengalaman langsung, bukan pada retorika atau kepintaran omong-nya.

\section{b. Tidak Menggurui}

Tidak ada guru dan tidak ada murid yang digurui, semua orang yang terlibat dalam proses pendidikan ini adalah guru sekaligus murid pada saat yang bersamaan. Oleh karena itu dalam pendidikan kritis siswa dibebaskan dengan memperoleh hak sebagaimana guru dalam proses pembelajaranya. Siswa bisa memberikan pendapat serta mengkritisi argument yang dimilikinya tanpa ada sekat pemisah apapun yang memisahakn antara peserta didik dengan guru.

\section{c. Dialogis}

Dalam pembelajaran secara umum, banyak pendidik yang melakukan pembelajranaya dengan tanpa interaksi bersama siswa, lebih cendrung hanya mengajari, mencontohkan dan tanpa memberikan ruang gerak bagi peserta didik untuk berdialog. Dalam pendidikan kritis proses dialogis yang membangun antara siswa dan guru. Proses berlangsungnya belajar mengajar bersifat komunikasi dalam berbagai bentuk kegiatan (diskusi, kelompok bermain, dan sebagainya), dan media (peraga, grafik, audio-visual, dan sebagainya) yang lebih memungkinkan terjadinya dialog kritis antara semua orang yang terlibat dalam proses pembelajaran tersebut. ${ }^{21}$ Semua hal di atas merupakan tujuan ideal pendidikan, namun bagaimana kenyataan di lapangan? Ternyata, praktik pendidikan yang terjadi justru sebaliknya. Pendidikan dijadikan cara untuk melanggengkan doktrin tertentu dan

${ }^{20}$ Mansour fakih, Op Cit. hal. 22

21 Ibid, hal. 105 
sebagai alat hegemoni kekuasaan. Peserta didik hanya dijadikan objek dan dilatih untuk menjadi penurut dengan tujuan keseragaman nasional. Apabila hal ini terjadi, pendidikan tidak lagi mampu menjadikan manusia sebagi insan kamil, tetapi justru menjadikan manusia sebagai robot-robot kekuasaan yang tidak bisa berpikir secara kritis dan bebas terhadap realitas yang ada di sekelilingnya. Kenyataan inilah yang kemudian menjadikan manusia mengalami kehampaan eksistensi sebagai manusia yang pada dasarnya secara fitriah memiliki potensi berpikir bebas dan berkesadaran.

Itulah dasar dari pendidikan pembebasan Mansour Fakih yang dalam tataran penerapanya menggunakan proses pendidikan kritis yang membangun serta menjadikan peserta didik untuk ikut andil dalam pembangunan masyarakat yang berperadaban.

\section{Kritik Wacana terhadap Pendidikan Mansour Fakih}

Sebenarnya paradigma pendidikan yang digagas oleh Mansour Fakih mempunyai titik temu yaitu pendidikan sebagai proses pemerdekaan manusia. Bagi dia, pendidikan dimaknai sebagai langkah awal untuk menumbuhkan kesadaran kritis pada setiap manusia sebagai wujud dari pelaku sejarah. Karena kesadaran kritis hanya akan bisa dicapai apabila orang itu telah sukses memaknai realitas dan belajar mmemahami lingkungan mereka dengan perantara dunia disekitar mereka. Sedangkan proses yang paling tepat untuk mencapai kesadaran tersebut adalah lewat pendidikan.

Kadangkala ada sebagian manusia yang tanpa melalui proses pendidikan sudah bisa belajar sekaligus memahami realitas yang ada disekitarnya, namun pemahamanya tidak bisa utuh dan menyeluruh hal ini disebabkan oleh tidak adanya proses analisis yang sistematis. Dalam konteks inilah seseorang membutuhkan sebuah proses pendidikan yang dilakukan dengan kesadaran untuk belajar memahami realitas yang ada secara bersama-sama dengan metode dan analisis yang tepat, sehingga bisa menemukan akar dari permasalahan yang ada. Maka dari sinilah seseorang itu menjalani penyadaran. ${ }^{22}$

Penyadaran adalah hal pertama yang harus dilakukan untuk membuka tabir-tabir keterasingan dan penindasan yang menyelimuti kalangan manusia. Kesadaran kritis dalam proses pembebasan manusia menjadi sangat penting, karena hanya kesadaran dan mentalitas yang tercerahkan, jernih dalam melihat realitas dan waawasan kemanusiaan yang baru yang menentukan terjaadinya transformasi sosial. Dengan kesadaran kemanusiaan yang luhur manusia akan menjadi penentu atas terciptanya struktur hidup yang harmonis. ${ }^{23}$

Paradigma pendidikan pembebasan Mansour Fakih mempunyai hubungan yang kuat dengan pendidikan penyadaranya Paulo Freire. Menurut Freire, untuk mengatasi kelemahan pendidikan perlu menciptakan sikap-

22 Paulo Freire, Pendidikan Sebagai Praktek Pembebasan, (Jakarta: 1984), hal. 41

23 Ibid., hal. 32 


\section{6 | Konsep Pendidikan Pembebasan Mansour Fakih}

sikap kritis. Dalam hal ini pendidikan yang dibutuhkan adalah pendidikan yang membuat berani membicarakan tentang masalah lingkunganya dan mau ikut dalam lingkungan tersebut serta mampu memperingatkan manusia terhadap bahaya zaman yang mengekang. Bukan pendidikan yang membuat kita tunduk patuh terhadap keputusan orang lain.

Dengan mengajak manusia terus menerus melakukan penilaian, menganalisis penemuan-pnemuan, menggunakan metode dan juga proses ilmu pengetahuan serta melihat diri sendiri dalam hubungan dialektis dengan realitas sosial, pendidikan akan membantu manusia dalam menciptakan sikap kritis terhadap dunia dan mengubahnya. ${ }^{24}$

Bagi Fakih, pendidikan adalah praktek pembebasan, bukan sekedar pengalihan atau penyebaran ilmu pengetahuan atau kebudayaan belaka. Pendidikan juga bukan merupakan perluasan teknis dan tindakan menanamkan laporan teknis atau fakta kedalam diri terdidik serta bukan hiasan nilai kebudayaan semata. Pendidikan juga bukan hanya mengadaptasi anak didik kedalam lingkungan saja. ${ }^{25}$

Oleh karena itu, pendidikan sebagai praktek pembebasan terutama sekali merupakan situasi yang sungguh-sungguh harus diperjuangkan. Dari sana tindakan mengetahui tidak memperoleh maknanya terutama dari objek yang dapat diketahui. Dalam proses pendidikan bagi pembebasan, guru dan murid sama-sama menjadi subjek kognitif di hadapan objek pengetahuan yang menjembatani mereka.

Maka dari itu, pendidikan yang membebaskan adalah pendidikan yang menekankan pada relasi yang satara antara guru murid dan guru. Memberikan kebebasan pada setiap peserta didik untuk saling berpendapat, menganalisa dan mengkritik gurunya jika perlu. Pendidikan ini mengutamakan pengetahuan pemahaman akan realitas objektif dengan segala ketimpangan dan kontradiksi di dalamnya. Dan usaha untuk memupuk solidaritas untuk menuntaskan kemiskinan dan penindasan secara struktural juga tidak boleh dinafiikan.

Sebenarnya guru dan murid bisa digambarkan dalam relasi yang sama, sebab keduanya sama-sama mempunyai sumber ilmu untuk bersama menggali pengalaman hidup. Setiap manusia mempunyai pengalaman sendiri tentang kehidupanya, maka dia memiliki ilmu yang setara denga yang lainya. Pola hubungan yang setara ini memberikan peluang bagi datangnya ilmu dari segi manapun. Tidak ada yang bisa memonopoli sumber apalagi ilmu pengetahuan dan kebenaranya. Pengalaman adalah sumber utama dalam keilmuan.

Model pendidikan pembebasan selain menjadi hal yang efektif juga sangat membantu masyarakat untuk membangun sikap yang kritis dan pencerahan bagi pendidikan. Dampak dari pendidikan ini akan menjadi masyarakat yang tumbuh dan berkembang dalam pendidikan atau dengan kata lain masyarakat yang belajar dan masyarakat terdidik. Masyarakat belajar adalah model masyarakat yang selalu siap menjawab tantangan dan

24 Ibid., 34

25 Mansour Fakih, et al, Pendidikan Populer "Membangun kesadaran Kritis", (Yogyakarta: INSITPress, 2001), hal.xi

\section{Kelola: Journal of Islamic Education Management}


kebutuhanya sendiri, dimana mereka selalu menawarkan solusi yang layak bagi kelangsungan hidup dan kebutuhan baik secara pribadi maupun orang lain.

Model dari masyarakat yang belajar tidak akan bergantung oleh fasilitas atau ruang yang diberikan oleh Negara yang justru akan mengganggu dan membelenggu serta mengontrol kebebasan. Pada masyarakat ini pendidikan dianggap sebagai kebutuhan dari dan untuk mereka yang tanpa harus terjebakk dan bergantung dari instansi secara resmi karena kesadaran untuk belajar sudah melekat dalam pemikirann mereka sedangkan untuk menciptakan masyarakat seperti itu dibutuhkan individu yang terdidik secara mandiri, bebas, kreatif dan inovatif.

Proses yang ada di dalam sistem sekolah saat ini adalah hanya menguntungkan siswa yang mampu saja yang relative sedikit, akan tetapi meminta tumbal tergusurnya anak-anak kaum bawah yang lemah. Sekolah telah memperbudak orang dengan cara sistematis, karena hanya sekolah yang dianggap mampu menjalankan tugas utama yaitu membentuk nilai kritis. Pemahaman yang demiikian itu telah membuat ketergantungan bagi kita sehingga tidak dapat membebaskan diri dengan cara apapun. Oleh krena itu masing-masing dari kita mempunyai tanggung jawab untuk membebaskan kebudayaan dan struktur sosial dari persekolahan. ${ }^{26}$

Penulis berpandangan bahwa pergumulan Fakih dalam dunia pendidikan tidak saja bergerak dalam tatanan epistemologis dan ontologism saja, akan tetapi sudah menjalar pada ranah aksiologis yaitu mempraksiskan ide-idenya yang sangat membangun melalui dunia pendidikan.

\section{Kesimpulan}

Setelah mengkaji pemikiran Mansour Fakih tentang pendidikan yang meliputi pendidikan kritis yang membebaskan, maka dapat disimpulkan dalam beberapa bagian berikut: (1)Bahwa pendidikan di Indonesia ini telah mengalami kemerosotan nilai penghargaan terhadap peserta didik, oleh karena itu, Mansour Fakih menempatkan peserta didik sebagai manusia yang berpotensi dalam mengembangkan dirinya. Salah satu konsep yang digagas oleh Mansour Fakih dalam memebebaskan peserat didik dari belenggu ketertindasan sistem kapitalis, pendidikan monoton, pendidikan yang tanpa memberi ruang bebas untuk berfikir kritis bagi peserta didik yaitu pendidikan kritis. Selain itu, pendidikan pembebasan Mansour Fakih ini juga mempunyai komponen-komponen diantaranya adalah Metode dalam pembelajaran, dan juga guru disebut sebagai fasilitator yang akan mengantarkan peserta didik dalam mengembangkan pendidikanya, (2)Pendidikan Islam juga dikatakan sebagai satu pranata sosial yang tidak hanya melihat bahwa pendidikan itu sebagai upaya mencerdaskan semata, melainkan sejalan dengan Islam tentang manusia dan hakekat eksistensinya. Oleh karena itu pendidikan Islam juga berusaha menumbuhkan pemahaman dan kesadaran bahwa manusia itu sama didepan Allah. Perbedaanya adalah

${ }^{26}$ Ivan Illich, Bebas dari Sekolah, (Jakarta: sinar Harapan, 1982) hal. 55 
kadar ketaqwaanya sebagai bentuk pembedaan secara kualitatif. Paradigma Islam tentang pembebasan sama dengan misi yang dibawa oleh Nabi Muhammad SAW. Ajaran tauhid sebagai kunci pokok ke-Islaman dengan jelas menunjukkan bahwa tidak ada penghambaan atau penyembahan keculai kepada Allah serat bebas dari belenggu apapun. Dengan kata lain bahwa seseorang yang telah mengikrarkan diri dengan kalimat syahadat berarti melepaskan dirinya dari belenggu yang mengekangnya

Melihat Problematika yang dihadapi dunia pendidikan saat ini, maka penulis berharap tulisan tentang pendidikan ini bisa memberikan sumbangsih sebagai berikut: (1)Pemikiran pendidikan pembebasan Mansour Fakih tentu tidak semudah itu diterapkan di Indonesia ini, namun tiada salahnya jika dipakai bahan perenungan bagi praktisi pendidikan saat ini, (2) Pendidikan dalam proses pembelajaranya memang harus sesuai dengan corak kultur dimana pendidikan tersebut ada, namun tidak bisa dilepaskan dari peran semua pihak pelaku perubahan pendidikan untuk menggagas konsep pendidikan pembebasan yang memang belum semua diterapkan didunia pendidikan, dan (3)Para pengampu pendidikan harus melihat realita yang terjadi di dunia pendidikan saat ini, dan semoga tulisan ini bisa dijadikan rujukan guna memperdalam teori sekaligus gagasan tentang pendidikan.

\section{Daftar Pustaka}

Aliah Darma, Yoce. (2009). Analisis Wacana Kritis. Bandung: Yrama Widya. Andre Yuris, Studi Analisis Wacana Kritis, diakses pada tanggal 13 Januari 2013 dari http://andreyuris.wordpress.com

Azzet, Muhaimin, (2001)Pendidikan yang Membebaskan. Yogyakarta: Ar-Ruz Media.

Bungin, Burhan, (2010). Penelitian Kualitatif. Jakarta: Prenada Media Grup.

Fakih, Mansour, et.al., (2005). Pendidikan Populer, Membangun Kesadaran Kritis. Yogyakarta: INSIST Press.

Fakih, Mansour (2001), Sebuah Pengantar dalam buku Francis Wahono, Kapitalisme penddikan Antara Kompetisi dan Keadilan, Yogyakarta: Pustaka Pelajar.

Fakih, Mansour (2011) Jalan Lain Manifesto Intelektual Organik, Yogyakarta: Pustaka Pelajar

Fakih, Mansour (1996) Masyarakat Sipil dan Transformasi Sosial, Yogyakarta: Pustaka Pelajar

Fakih, Mansour (2009), Runtuhnya Teori Pembangunan dan Globalisasi, Yogyakarta: INSIST Ppess.

Freire, Paulo, (1984) Pendidikan Sebagai Praktek Pembebasan, Jakarta: Gramedia

Illich,Ivan, (1982) Bebas dari Sekolah, Jakarta: sinar Harapan. 
Moleong, Lexi J (2007), Metodologi Penelitian Kualitatif, Bandung: PT Remaja Rosda Karya

Mukhtar, Erna Widodo. (2000). Konstruksi ke Arah Penelitian Deskriptif. Yogyakarta: Avyrouz.

M. Pidarta, (1999). Studi tentang Landasan Kependidikan; Jurnal, Filsafat, Teori dan Praktik Kependidikan. Jakarta.

Syaodih Sukmadinata, Nana, (2007). Metode Penelitian Pendidikan. Bandung: Rosda Karya

Prasetyo, Eko, (2006). Guru: Mendidik itu Melawan. Yogyakarta: Resist Book

Tafsir, Ahmad (2006). Filsafat Pendidikan Islami: "Integrasi Jasmani, Rohani dan Kalbu Memanusiakan Manusia" Bandung

Mudjia Rahardjo, Analis Wacana dalam Studi Keislaman Sebuah Pengantar Awal, diakses pada tanggal 13 Januari 2013 dari http://mudjiarahardjo.com/artikel/230-.html.

(2007). Politik Pendidikan: "Kebudayaan, Kekuasaan dan Pembebasan". Yogyakarta: Pustaka Pelajar. 
100 | Konsep Pendidikan Pembebasan Mansour Fakih

HALAMAN INI SENGAJA DIKOSONGKAN 